\title{
THE IMPORTANCE OF THE EUROPEAN SPACE AGENCY'S ACTIVITIES FOR THE SECURITY OF THE EUROPEAN UNION
}

The purpose of this paper is to demonstrate that the activities of the European Space Agency (ESA) make a significant contribution to the security of the European Union. Initially, neither the ESA's activities nor the original objectives for which it was established were connected with security issues. The ESA evolved from an international intergovernmental organization focused on the exploration and use of space for peaceful purposes into a major player with a significant impact on the security of the EU. The presumption made by this paper is that in order for this evolution to be possible, both the ESA and the EU have had to go a long way to find common ground and forms of possible cooperation, preceded by the required political and programmatic changes. For the EU, which was relatively late in taking an interest in space and its importance for security, space policy became a separate policy only under the Lisbon Treaty. At that time the EU granted to itself (shared) powers in this area. The paper will identify the most important reasons for and stages of this evolution, as expressed in policy documents. As this is still an ongoing process, remaining obstacles to the optimal use of the potential of both organizations to strengthen the security of the European Union will be identified. The paper was created on the basis of the descriptive method, analysis of the content of documents and synthesis.

Since the beginning of the space age, space technologies have become very popular, to such an extent that today it is difficult to imagine our world without them. This applies to technologies used for both civilian and military purposes. Both the former and the latter serve, or may serve, to ensure security, but also may pose a serious threat, due to the increasing dependence of states and societies on space systems. There is a wide range of potential threats, from the possible use of anti-satellite weapons to hybrid operations and cyber-attacks that may disrupt or destabilize the functioning of the state. The contribution of European space systems as tools for the implementation of the Common Security and Defense Policy has been steadily increasing. As Europe faces ever-changing security threats that are more and more diverse, less predictable, and global in scope, the first line of response to crisis situations should already be outside of its borders. The space potential, in particular space assets and services, are priceless from the point of view of threat monitoring, early warning, surveillance, navigation and communication. It is therefore essential 
for the European Union to ensure independent access both to outer space and to the technologies that provide the best opportunity for rapid assessment of the situation, quick decision-making and the effective conduct of operations. The European space infrastructure is expected to fulfill EU's security related needs. This system of information on the situation in outer space is known as the Space Situational Awareness (SSA). One also cannot overestimate the strategic importance of the space sector, which increases the security of countries developing it, as an instrument to support technological innovation. However, this aspect, as well as the impact of space policy on a full-scale pro-innovation policy accelerating the technological development of the economies of modern states and the importance of space policy will not be analyzed in this paper.

Countries with advanced space programs (the USA, Russia and China) make the most use of the space medium for security purposes, resulting, inter alia, in increased competition between them. However, while the US seeks to gain the advantage in space in order to ensure unhindered access to outer space in all circumstances, while at the same time being able to deprive its opponents of this opportunity (without ruling out the possibility of outer space weaponization in the future) (U.S. National, 1996: 4; National Space Policy, 2006; National Space Policy, 2010: 14), Russia and China are more in favor of strengthening multilateral mechanisms to prevent the placement of weapons in space. Space policy and its objectives are reflected in the military/space strategies of these countries.

Against this background, the European Union emerged as a relatively young space player, with, however, significant potential and resources, as well as advanced space infrastructure. Despite the fragmentation of EU space activities between different agencies, organizations and individual countries, the EU also has shared interests in this field, progressively pursuing autonomy in its space programs (becoming independent from both the US and Russia) (Dokument roboczy, 2008: 6), the prevention of the outer space weaponization, and the adoption of an international regime governing states' activities in space (Bryła, 2015b). As the EU strives to obtain this status, the European Space Agency has a special role to play. While the ESA, by its very nature, from its very beginning has dealt with space, security issues were not part of its remit or field of interest. At the same time, the EU did not deal with space at all, with only some of its member states having national space programs. Therefore, for both entities, the need to adapt to new, rapidly changing needs and circumstances was both a political and an organizational challenge.

The European Space Agency was founded with a Convention signed in Paris on May 30, 1975, following the merger of the European Space Research Organization (ESRO) and the European Launcher Development Organization (ELDO). It is an international, intergovernmental organization dedicated to implementing a joint European program for the exploration and exploitation of outer space. Its operations cover a wide range of activities, including astronautics (astronomy and astrophysics), Earth observation, telecommunications, navigation, manned and unmanned space flights, launchers and meteorology, as well as research and development in all these fields. Its activities also include supporting the development of modern and competitive industry in member states (Space security, 2016: 71). 
The activities of the ESA are aimed at expanding knowledge about the Earth and its immediate environment, the Solar System and the Universe, as well as developing space exploration technologies and promoting European industry, but also at enabling its economic exploitation. In addition, the organization coordinates the various objectives of member states' national space policies. While the Agency is fully independent, it does work closely with the European Union, alongside which it implements the main guidelines of the space strategy. The Agency's main objectives are: to conduct activities on outer space research and exploitation for scientific purposes; to develop and implement a long-term European Space Policy, to make recommendations on the purposes of space activities and to coordinate national space policies; to coordinate the European Space Program with national programs and to integrate national programs into the European Program; to develop and implement an industrial policy in the space sector within the framework of its own programs; and to make recommendations for coherent policies in this field to member states (Convention, 2003: Article II).

The management of the ESA's resources is based on the Geographical Return principle, whereby industrial contracts are distributed in such a way that contracts with a value close to a country's contribution to the ESA budget are placed with companies from that particular country (the rate of return on a contribution is around $90 \%$ ). This is to encourage countries to allocate more resources to this purpose than they would have done otherwise. The Agency operates in a flexible manner, so that it can meet the expectations and needs of member states. Some countries are interested in carrying out large-scale activities (e.g. France and Italy), while others, for various reasons (e.g. different political priorities, lack of sufficient resources, etc.), participate in the Agency's programs to a more limited extent.

The ESA runs two types of programs: mandatory and optional. All member states are obliged to participate in the mandatory programs, which are financed by the individual member states' contributions in proportion to their gross domestic product (GDP). This includes, inter alia, space exploration and the construction and use of equipment for space exploration. Optional programs are financed by the participating countries. Participation is determined in negotiations on a program-by-program basis. The scope of the optional programs is not clearly defined. Optional programs are related to, among others, observation of the Earth and objects in its vicinity, telecommunications, satellite navigation, and space transportation. They also include the development of a European space launcher and programs for practical applications of space technologies (Europejska, 2017). The ESA does not seek to carry out operational activities - once the systems have been developed to a level at which they can enter the practical application phase, the Agency hands them over to related organizations which are responsible for maintaining, operating and developing the systems further (often in cooperation with the ESA), and for running an appropriate commercial policy. These organizations include Arianespace, which is responsible for the use of the Ariane launcher, Eutelsat, which is responsible for telecommunications, and Eumetsat, which is responsible for meteorological satellites.

In the case of space activities, science, technology and security are closely intertwined, while space technologies often have dual civilian/military applications. Decisions on how to use outer space are therefore political in nature, which has an indi- 
rect impact on international peace and security. The example of many countries so far shows that the security sector is the most prolific user of satellite systems, often even determining the direction of their development. Technologies created and developed for the military sector in due course find civilian applications, e.g. Earth observation techniques, related to the development of aviation, or GPS satellite navigation (Sektor, 2017).

The relationship between space and security is becoming increasingly important as most of the data and information used in the military and security sector is provided by space systems. As underlined by the European Commission in its document $E U$ Space Industrial Policy Releasing the Potential for Economic Growth in the Space Sector, "these systems and services guarantee the independence and security of the EU" (Communication, 2013: 3). Developing space potential helps to improve both the external and internal security of the European Union. The demand for satellite services for military and security applications has increased in recent decades due to the growing participation of European military and security forces in foreign expeditionary missions (operations in Afghanistan and Libya, peacekeeping and peace enforcement, as well as humanitarian missions under the Common Security and Defense Policy, etc.). On the other hand, elements of existing space infrastructure are vulnerable to destruction or damage caused both by natural phenomena and by man-made objects (deliberate or unintended). Only a few countries have the technology to respond to some of these threats, and the lack of EU coordination mechanisms for such endeavors makes the protection of EU space infrastructure highly dependent on the resources and goodwill of non-EU countries (Bryła, 2015a).

As the emerging threats are not purely military in nature, they cannot be countered or combated by military means alone. Space technologies can support security in terms of both risk management and dealing with emerging threats. The EU wants to be able to act at all stages: risk prevention, early warning, crisis management, and helping victims of disasters. Space assets can provide the necessary flexibility to respond, thanks to satellites dedicated to telecommunication (communication), navigation (positioning) and electronic intelligence (reconnaissance and surveillance). Once in orbit, these systems become critical infrastructure that requires full protection against both deliberate and unintended threats. The objective of achieving 'security in space' can only be attained by developing a Space Situation Awareness to track possible threats to both space assets and ground systems. In order to guarantee both 'security from space' and 'security in space' and to develop European and national space policies, it is essential to have the autonomous capability to send objects into space. In this regard, the EU is working hard to make itself independent from the US and Russia.

The initial lack of involvement of the ESA in security and defense matters (as provided for in its Statute) in recent years has been giving way to ever closer cooperation with the EU in this field. The Agency has created a legal framework to cope with its increasing security requirements, is increasingly involved in ensuring cyber-security and, together with the European Defense Agency (EDA) and the European Commission, is developing ways to strengthen its strategic independence in the field of critical space technologies. However, before the ESA became an important part of the network of actors responsible for various aspects of security in the European Union member 
states, it had to find a formula in which the above could be performed by an international intergovernmental organization which, in principle, should deal exclusively with matters of science and space exploration for peaceful purposes. The European Union, in turn, had to integrate outer space into its security policy.

What follows describes the key phenomena and events that triggered the process of rapprochement of these actors, and the documents that reflected it.

I. The dynamic changes taking place in the security environment of the European Union, including the emergence of new phenomena identified by its members as threats, led gradually to them being reflected in EU documents. A change in the nature of many threats, and the emergence of diverse new ones (internal and external, regional and global, civilian and military, natural and man-made), required, first of all, the precise identification of these threats, followed by the development of strategies to counter them, and the gathering of the necessary tools to counteract them. The evolution of the main strategic documents related to the security of the European Union reflected the process of these changes.

The European Security Strategy of 2003 takes a broad approach to security. Objectives arising from this strategy include peacekeeping operations, protection of critical infrastructure and common external borders, prevention of the proliferation of weapons, and verification of agreements (Dokument roboczy, 2008: 2). While this strategy identifies five key threats, i.e. terrorism, the proliferation of weapons of mass destruction, regional conflicts, the collapse of statehood, and organized crime (European Strategy, 2003), in 2008 cybersecurity, energy security and climate change were added (Czachór, 2010: 32). By 2010, cybercrime, cross-border crime, violence itself, and natural and man-made disasters were added to the list of key threats (Strategia bezpieczeństwa, 2010: 13-14). In 2015, terrorism, cross-border crime and cybercrime were again among the priorities (Europejska agenda, 2015: 2). With the evolution of the landscape of threats, in the new EU Global Strategy on Foreign and Security Policy of 2016 the list was expanded to include hybrid challenges and threats, and management of external borders (Wspólna wizja, wspólne działanie, 2016: 7). Such a wide range of global challenges and catalogs of threats requires a diversified set of instruments and response capabilities. The European Union has long considered the capacity to respond comprehensively to security threats a priority, recognizing that complex and interdependent challenges require action on multiple levels, and, in the longer term, the management of crises and efforts to address their root causes.

II. The growing importance of outer space for national politics, economies and security has resulted in the need to protect the EU's space assets. In today's security environment, which is characterized by an increase in unconventional threats (terrorism, cross-border organized crime, the proliferation of weapons of mass destruction), countries need to be aware of what is happening in their immediate and more distant environment, and remain capable of acting effectively. This would be impossible without the extensive use of satellite techniques, starting with satellite observation, through the monitoring of borders and international developments, to early warnings about non-typical phenomena or activities and techniques supporting foreign missions, improving command capabilities, or facilitating data collection and analysis. The increasing use of satellite techniques in rescue operations and crisis management is also 
important. As a result, outer space is inevitably becoming another area of international struggle, as are the areas of land, sea, air and cyberspace.

III. For the European Communities, and subsequently for the EU, space has remained for a very long time exclusively the domain of research and scientific development, with little political relevance. Only new trends, both qualitative and quantitative, which emerged with the end of the Cold War have forced this approach to change. Space systems have begun to be perceived as powerful tools to achieve a wide range of objectives in different fields of security (economic, social and environmental). At the same time, the number of countries and commercial actors involved in space activities has increased, while new applications have proven to go far beyond the achievement of political objectives characteristic of the Cold War period. In an effort to increase the security of its members by becoming independent from external actors (notably the US) in terms of space infrastructure, the EU has been systematically developing its own, which paradoxically makes it more sensitive and vulnerable to threats, increasing the demand for the protection of space assets. This is even more important as, at the same time, the economic dependence of EU citizens on space services is also increasing. Despite the above, for a long time, most EC/EU security documents have not highlighted the link between security and space, and the strategic, political and military importance of space practically has not been taken into account at all. Rather, the focus has been on scientific programs in space and civilian applications which are within the scope of the ESA. The European Union itself did not have any jurisdiction over space activities. The gradual shift taking place in this area is best illustrated by the evolution of the content of the main strategic documents relating to EU security.

IV. In the next phase, the EC/EU started to integrate space into its policies and documents (programmatic evolution) and assigned itself powers related to space and space policy. While cooperation in the field of space policy in Europe has been ongoing since the 1960s, it is only since the 1980s that the European institutions have begun to adopt key documents contributing to the development of a coherent European space policy. One of the first of these documents was issued by the Commission of the European Communities on July 26, 1988, on a common approach to the field of space. Since then, the Communities' political and legal aquis has been steadily growing, demonstrating the growing interest of the European institutions in matters of outer space. This was reflected, inter alia, in the adoption of a number of important documents defining the framework for the joint space activities of the two organizations. The most important of these are specified below.

1. Communication of the European Commission of 27 September 2000 Europe and Space: Turning to a new chapter, announcing the creation of a coherent European space policy (Europe, 2001).

2. Council Resolution of 16 November 2000 on a European space strategy (Council, 2000). Under the above, on March 2, 2001, the EU and ESA established the Joint Task Force (JTF) on the European Strategy for Space, which implemented the guidelines of the strategy, such as increasing the use of space potential to benefit for the market and industry. The document also highlights the importance of ensuring Europe's independent access to space for its political position on the international scene. The resolution sets out two main lines of action for the EU: the development of the European satel- 
lite navigation system Galileo, and work on the development of an independent Earth observation system (GMES).

3. A document adopted by the European Commission on December 7, 2001 entitled Towards a European space policy. The European Commission and the European Space Agency Joint Task Force report (Towards, 2002), in which the Commission stressed the need to integrate the space sector into a broader pan-European political and economic strategy. The EU has recognized that, given the wide range of potential applications, space activities should be the subject of a separate policy.

4. In response to the European Parliament's demand, voiced in July 2002, for a White Paper on Space, the European Commission, in cooperation with the ESA, published a groundbreaking document in 2003 - Green Paper. European Space Policy (Green, 2003). The Paper provides an overview of the top space policy issues developed jointly by the Commission and the ESA within the Joint Task Force framework since 2001. Particular emphasis is placed on the need to raise awareness of the strategic and political importance of space for the EU, and to launch a debate on space policy involving all stakeholders.

5. In November 2003, the European Commission published the White Paper. Space: a new European frontier for an expanding Union. An action plan for implementing the European Space policy (White, 2003). This document defined the areas of EU space activity and postulated expenditure related to different scenarios. It was preceded by a several-year-long debate on whether the EU (unlike the ESA) should take a leading role in the development of a European space policy. Space was identified as strategically important for the independence of the European Union, the creation of new jobs, and competitiveness. In order to achieve its objectives, the EU had to develop and implement its own space policy. Space activity was inscribed into the emerging Constitution for Europe.

6. The need for closer cooperation between the European Space Agency and the European Union led to the conclusion of a Framework Agreement. In 2003, the ESA initiated work on Space and Security Policy in Europe as part of its General Studies Program. However, the evolution of the Common Foreign and Defense Policy and the European Security and Defense Policy required a more integrated approach to security. To this end, the European Union and the European Space Agency agreed to strengthen their contacts by signing a Framework Agreement in 2004 (Framework, 2004), on the basis of a decision of the Council. The two organizations sought to establish a coherent space policy that would meet Europe's needs and aspirations, and strengthen its position in the world. The aim of the space policy was to ensure the development of industry and scientific research, and the best possible use of the opportunities offered by space technologies to strengthen the competitiveness of the European economy.

7. The development of a single EU space policy required the setting of priorities. Therefore, in 2005, the European Commission came to the conclusion that space was becoming "a key element of the EU's top policies" (Communication, 2005: 5). As a result, more attention was given to the security of the space environment, while space assets themselves acquired strategic importance as vital tools of the military and economic power of states, requiring protection. 
8. The EU's growing interest in space increased the need for the development of a comprehensive space policy. As a result, the European Union, the European Space Agency, and member states jointly developed a European Space Policy, which was the culmination of a long process reflecting the growing cooperation between these actors. On May 22, 2007, the Space Council (i.e. the ESA Council of Ministers and the EU Competitiveness Council, meeting jointly) approved a resolution establishing a European Space Policy (Communication, 2007). The document aimed to unify and harmonize the work of the two organizations, and also to set strategic objectives for the EU's future space activities, defining its priorities and key functions. The basic principles of the European Space Policy were set out in a Resolution of the Space Council (Archiwum, 2007). The previous separate programs were combined, with the assumption that satellite technologies for defense would be used for civilian purposes. It was underlined that the space sector is a strategic resource, contributing to Europe's independence and security. Recognizing that space technologies often have both civilian and defense applications, the document's authors recommended stronger coordination of defense and civilian space programs, particularly in the field of security. The importance of the European Space Policy also lies in the fact that it is the first fully-fledged joint document on all dimensions of space activities, developed and adopted after extensive consultation with EU and ESA member states, as well as industry representatives and other stakeholders, and endorsed by member states. The legal basis for the European Space Policy is laid down in Article 189 of the Treaty on the Functioning of the European Union (TFEU), which gives the EU powers shared with member states on space matters. This has allowed the EU to present two flagship programs, namely GMES/Copernicus (Global Monitoring for Environment and Security) and Galileo (Gruszczak, 2014: 99-100). According to Article 189, in order to promote scientific and technological progress, industrial competitiveness, and the implementation of its policies, the EU will develop a European space policy, promote joint initiatives, support research and technological development, and coordinate the efforts necessary for the exploration and exploitation of space. In this way, the EU and ESA created a political and legal framework for cooperation in the field of space policy, which is defined by the conventions, treaties, and documents of both intergovernmental organizations.

9. Since 2007, the EU, ESA and their member states have also been increasingly involved in political and diplomatic initiatives for space security and the idea of sustainable development of the space environment, inter alia through the EU's proposal to establish an International Code of Conduct for Outer Space Activities, (ICoC) (Bryła, $2015 b$ ). Its objective is to improve the security and stability of operations in space, to build trust between space actors, and to reduce the formation of space debris.

10. In July 2008, the European Parliament adopted the Resolution of 10 July 2008 on Space and security (European, 2008), underlining the importance of space potential for EU security and the fact that the European Space Policy should not contribute to the militarization and weaponization of outer space.

11. In September 2008, a Resolution of the Space Council identified space and security as one of the four new EU priorities, underlining the important contribution of the space medium to CFSP/ESDP and the security of European citizens (Commission, 2008). 
12. A breakthrough in the evolution of the role of the ESA as an important actor for the security of the EU was the coming into force of the Lisbon Treaty in 2009, establishing space policy as a separate EU policy (Treaty, 2007: Art. 2c.3). Under this Treaty, the European Union, for the first time ever, obtained specific powers (shared between the EU and its member states) on space matters (Treaty on the Functioning, 2007: Art. 4.3). Since then, one of the aims of the European Space Policy has been the integration of space activities into other EU policies, including transportation and environmental protection.

13. A further step towards closer cooperation between the EU and ESA was the European Space Program developed in 2012, forming an integrated plan defining the type of activities, roles and responsibilities of participants, sources of funding and basic principles for its implementation. The body supervising this process is the Space Council. The purpose of the Program is to, inter alia, ensure Europe's independence in space-based activity in strategically important areas (such as satellite launch capabilities and satellite observation capabilities). Thus it can be expected that the ESA will be involved in an increasing range of space security functions.

V. The European Space Policy has transformed to take into account evolving security needs and, alongside this, the scope of the ESA's activities is changing. The ESA's impact on EU security increased following the launch of the European Framework Cooperation (EFC) on civil protection, security and space-related research by the European Defense Agency (EDA) in 2009. The purpose of the EFC is to coordinate research investments by the EDA, the European Commission and the European Space Agency, with particular focus on dual-use areas for civil security and military users, in order to avoid the duplication of research and to save resources. Examples of the EDA and ESA working together on space projects are the Multinational Space-based Imaging System (MUSIS) and a satellite-based data transfer system (Mazurek, 2012: 69). The 2011 EU Space Strategy identified the benefits of space technology and acknowledged that space infrastructure was both a security tool and a critical resource that had to be protected. Services in the area of security obtained from observation, navigation and communication satellites require seamless space security and system stability. It is therefore necessary to take appropriate measures to eliminate the threat to those assets and the environment in which they operate.

VI. The year 2016, after a longer break, abounded in documents important for the development of cooperation between the EU and ESA, including in relation to security. In November 2016, at the request of ESA and EU member states, both organizations presented a common vision and long-term objectives for the European space sector. These were subsequently confirmed by the Council of the ESA and the Council of the European Union as a focus of future cooperation. Both the common vision and the objectives took into account the importance of independent space technologies and policies for the security of the EU (Wspólna, 2016). What was highlighted as crucial was ensuring European autonomy in accessing and exploiting space as a secure environment, and in the protection of its own infrastructure. A month earlier, the European Commission announced a Space Strategy for Europe - the first document since 2011 setting out the objectives, assumptions and main development directions of European space policy (Frankowski, 2016). It underlined the importance of relations between 
the EU and ESA to effectively meet its objectives, taking into account the Agency's technical resources, professional expertise, technical capability and know-how (Communication, 2016).

VII. However, in order for the ESA to contribute more effectively to the security of the EU in the future, it will be necessary to overcome the obstacles which hinder cooperation between the two organizations, given that the main areas of activity of these organizations are different; for the ESA, space is the focus of its activity, while, for the EU, not only is space one priority among many, but additionally, the EU's powers and capabilities are shared with its member states. A number of difficulties related to the above are highlighted in the 2012 Communication from the European Commission to the Council and the European Parliament on the establishment of appropriate relations between the EU and ESA (Communication, 2012). This document identifies the following structural obstacles in the current relationship between the EU and ESA:

1. Incompatibility of financial regulations; the European Union and the ESA operate under different rules, which must coexist within the ESA. The funding for projects implemented by the EU is based on the principle of competitiveness, whereas the ESA does so on a geographical return basis. This generates problems, especially in the case of space programs which are co-funded by the ESA and the EU.

2. Asymmetric membership; the EU and ESA differ in membership, with the European Union having 28 member states while the European Space Agency comprises $21 \mathrm{EU}$ member states and Switzerland. This means that not all ESA member states are members of the European Union or NATO at the same time. For example, Switzerland - a founding member of and active participant in the European Space Agency - is not member of the European Union, nor are Canada and Norway (ESA members). Conversely, not all EU members are ESA members - Bulgaria, Cyprus, Latvia, Lithuania, Malta, Slovakia and Slovenia are currently aspiring to join the organization. The current voting system, whereby each member state has one vote in the ESA Council, while key decisions are adopted unanimously, gives disproportionate influence to the non-EU members of the ESA on important EU issues, including security matters.

3. Asymmetry in security and defense issues; as the EU increases its capabilities in security and defense matters, following the adoption of the Lisbon Treaty, the EU faces the task of strengthening the links between the civil and defense dimensions of activity in space. However, the fact that ESA members include not only non-EU but also neutral states complicates efforts to formulate a space policy around common security objectives for the EU. Neutral states in particular are very cautious about the potential military use of space.

4. The lack of policy coordination mechanisms; the 2004 Framework Agreement between the EU and ESA is not sufficient in terms of coordinating activities. The details must be negotiated on a case-by-case basis, as there is no political mechanism to ensure consistency between ESA activities and other fields of EU policy. This makes longer and complicates the implementation of any program.

5. The ESA's lack of political accountability (it does not report to the EP); one potential solution to this problem is the 'absorption' of the Agency by the EU. However, the EU Competitiveness Council in 2014 withdrew from the idea of transforming the ESA into a European Union agency. The ESA remains a separate intergovernmental 
organization, with legal personality in member states. The Council shared the European Commission's view that "transforming the ESA into an EU agency would require a political consensus that would be difficult to achieve in the foreseeable future" (Bartkowiak, 2014).

What should be added to this catalog of problems hindering cooperation between the ESA and the EU on matters of security are certain legal aspects of the operation of the ESA. Although neither the EU, as an international law entity (Polkowska, 2011), nor the ESA, as an organization, can accede to any of the five international treaties regulating space activities, the European Space Agency has formally notified the UN Secretary-General that it will respect the rights and obligations arising from the application of two of the five outer space treaties, i.e. the Convention on Registration of Objects Launched into Outer Space of 1975 and the Convention on International Liability for Damage Caused by Space Objects of 1972 (texts: United, 2002). As a result, although the EU owns and operates satellites, the satellites are registered by the ESA under the Convention of 1975.

However, perhaps the most important challenge facing the ESA, if it is to contribute to the security of the EU in a rapidly changing environment, is to strike a balance between the civilian and military use of space. This is necessary in view of the inevitable need for the Agency to go beyond its statutory objectives of "providing for and promoting exclusively peaceful cooperation between European States" (Convention: Article II). The requirement for the peaceful nature of the pursued objectives significantly restricts the ESA's activities promoting security. Therefore, in order to avoid any ensuing complications, the term 'peaceful' is increasingly interpreted as 'non-offensive' rather than 'non-military,' thus opening the door to dual (civilian-military) activities. This trend seems unavoidable, as shown by the example of the Ariane launch vehicles, which not only are created with the use of military technology but are also used to launch military satellites. Many of the EU's security functions are carried out with the help of satellites (border monitoring, intelligence gathering and, in the event of an armed conflict, the provision of the necessary intelligence to its own forces), which are part of the infrastructure developed for the Copernicus program, even though it was designed as a strictly civilian tool. Currently, most of the technologies used have dual applications.

There is no doubt that the ESA is now essential for the strengthening of European security and defense, as it enables independent access to space, the development of industrial infrastructure, ground infrastructure, and many key technologies and services for data collection, processing and dissemination. This is of fundamental importance for all types of EU actions and activities related to security matters. Any disruption of the availability and operation of space-based systems might have negative consequences for the security of EU member states. The ESA is also one of the few space agencies in the world which carries out activities in almost all fields of space activity (space science, space exploration, Earth observation, rockets, navigation, development of space technologies and their applications, telecommunications, manned space flights). Each of them is directly or indirectly connected with security, in the broadest sense of the term. The ESA, together with some national space agencies in Europe, and the UN Committee on the Peaceful Uses of Outer Space (UNCOPUOS) is also involved in activities to control space debris orbiting close to the Earth which poses 
a threat to space infrastructure. Nevertheless, it has to be said that the EU's investments in defense-only space activities remain relatively low compared to the leading space powers. Out of all the EU member states, only France, Germany, Italy, Spain and the United Kingdom have prioritized the development and ownership of defensive space programs. It can therefore be expected that the increased importance of ESA activities for the security of the EU will depend not only on the political will of the members of both organizations and the resources available, but also on the interests of the main investors in and beneficiaries of the programs carried out by the ESA, i.e. France, Germany, Italy, the United Kingdom and Spain.

\section{REFERENCES}

Archiwum wiadomości (2007), Polskie Biuro do spraw Przestrzeni Kosmicznej, http://www.kosmos. gov.pl/index.php?link=74\&news=42, (14.06.2018).

Bartkowiak H. (2014), UE odktada decyzję o zmianach w stosunkach z ESA, https://kosmonauta. net/2014/05/ue-odklada-decyzje-o-zmianach-w-stosunkach-z-esa/ (14.06.2018).

Bryła J. (2015a), Bezpieczeństwo kosmiczne w polityce Unii Europejskiej, w: W kręgu nauki o stosunkach międzynarodowych, (ed.) A. Dudek, Warszawa.

Bryła J. (2015b), Wkład Unii Europejskiej w rozwój międzynarodowego reżimu kosmicznego, „Rocznik Integracji Europejskiej”, No. 9.

Commission Working Document. European Space Policy Progress Report (2008), COM(2008) 561 final, Brussels, 11.09.2008.

Communication from the Commission to the Council and the European Parliament Establishing appropriate relations between the EU and the European Space Agency (2012), COM(2012) 671 final, Brussels, 14.11.2012.

Communication from the Commission to the Council and the European Parliament - European Space Policy (2007), COM(2007) 2012 final, Brussels, 26.04.2007.

Communication from the Commission to the European Parliament, the Council, the European Economic and Social Committee and the Committee of the Regions - 'Space strategy for Europe' (2016), $\operatorname{COM(2016)~} 705$ final, Brussels, 26.10.2016.

Communication from the Commission to the European Parliament, the Council, the European Economic and Social Committee and the Committee of the Regions - EU Space Industrial Policy Releasing the Potential for Economic Growth in the Space Sector (2013), COM(2013) 108 final, Brussels, 28.02.2013.

Communication from the Commission to the Council and the European Parliament. European Space Policy - Preliminary Elements (2005), COM(2005) 208 final, Brussels, 23.05.2005.

Convention for the establishment of a European Space Agency (2003), ESA SP-1271 (E), http:// www.kosmos.gov.p1/download/ESA_Convention.pdf (14.06.2018).

Council Resolution of 16 November 2000 on a European space strategy (2000), Official Journal of the European Communities, C 371, 23.12.2000.

Czachór Z. (2010), Europejska Strategia Bezpieczeństwa 2003-2008. Analiza politologiczna, „Przegląd Politologiczny” No. 2.

Dokument Roboczy Parlamentu Europejskiego w sprawie wktadu potencjatu kosmicznego w EPBiO (2008), Parlament Europejski, Komisja Spraw Zagranicznych, 30.01.2008, http://www.europarl. europa.eu/meetdocs/2004_2009/documents/dt/705/705615/705615pl.pdf, s. 6 (14.06.2018). 
Europe and Space: Turning to a new chapter (2001), European Commission, https://publications. europa.eu/en/publication-detail/-/publication/6d250993-e78d-4e43-b81c-e52488c0cbdb/ language-en (14.06.2017).

European Parliament resolution of 10 July 2008 on Space and security (2008), 2008/2030 (INI), http://www.europarl.europa.eu/sides/getDoc.do?type $=$ TA\&language $=$ EN\&reference $=$ P6-TA-2008-0365 (14.06.2018).

Europejska Agencja Kosmiczna (2017), Polskie Biuro ds. Przestrzeni Kosmicznej, http://www.kosmos.gov.pl/index.php?link=79\&sublink=91\&page=1 (14.06.2017).

Europejska agenda bezpieczeństwa (2015), Strasburg, 28.04.2015, https://eur-lex.europa.eu/legalcontent/PL/TXT/PDF/?uri=CELEX:52015DC0185\&rid=1 (25.05.2018).

Europejska Strategia Bezpieczeństwa. Bezpieczna Europa w lepszym świecie (2003), Rada Unii Europejskiej, https://www.bbn.gov.pl/ftp/dok/01/strategia_bezpieczenstwa_ue_2003.pdf (25.05.2018).

Framework Agreement between the European Community and the European Space Agency (2004), Official Journal of the European Union, L 261, 6.08.2004.

Frankowski P. (2016), Strategia kosmiczna dla Europy, „Unia Europejska.pl”, nr 6 (241).

Green Paper. European Space Policy (2003), https:/www.espi.or.at/images/documents/greenpaper. pdf (2.06.2018).

Gruszczak A. (2014), Technologie satelitarne na rzecz bezpieczeństwa Unii Europejskiej, „Kultura i Polityka: zeszyty naukowe Wyższej Szkoły Europejskiej im. ks. Józefa Tischnera w Krakowie", nr 16.

Mazurek K. Ł. (2012), Europejska Agencja Obrony. Działalność i perspektywy, Warszawa.

National Space Policy on August 31, 2006 (2006), https://www.globalsecurity.org/space/library/ policy/national/us-space-policy_060831.htm (25.05.2018).

National Space Policy of the United States of America 28 Jun 2010 (2010), https://www.globalsecurity.org/space/library/policy/national/100628_national_space_policy.pdf (25.05.2018).

Polkowska M. (2011), Prawo kosmiczne w obliczu nowych problemów wspótczesności, Warszawa.

Sektor bezpieczeństwa (2017), Polskie Biuro do spraw Przestrzeni Kosmicznej, http://www.kosmos. gov.pl/index.php?link=73\&group=5\&subgroup=10 (14.06.2017).

Space security for Europe (2016), EU Institute for Security Studies Report No. 29, Rapporteurs M. Pellegrino, G. Stang, https://www.iss.europa.eu/sites/default/files/EUISSFiles/Report_29_0.pdf (14.06.2018).

Strategia bezpieczeństwa wewnętrznego Unii Europejskiej Dążąc do europejskiego modelu bezpieczeństwa, (2010), JHA Council, March 2010, http://www.consilium.europa.eu/ media/30744/qc3010313plc.pdf (2.06.2017).

Towards a European space policy. The European Commission and the European Space Agency Joint Task Force report (2002), European Commission, https://publications.europa.eu/en/publication-detail/-/publication/34571434-a6d4-47eb-9614-030e6b0151d7 (14.06.2017).

Treaty of Lisbon amending the Treaty on European Union and the Treaty establishing the European Community, signed at Lisbon, 13 December 2007 (2007), Official Journal of the European Union, C 306, Vol. 50, 17.12.2007.

United Nations Treaties and Principles on Outer Space (2002), United Nations, New York.

U.S. National Space Policy Factsheet (1996), The White House, Washington, https://www.globalsecurity.org/space/library/policy/national/us-space-policy_060831.pdf.

White Paper. Space: a new European frontier for an expanding Union. An action plan for implementing the European Space policy (2003), COM(2003) 673, Brussels, 11.11.2003. 
Wspólna wizja i cele dla przyszłości Europy w kosmosie (2016), https://www.esa.int/pol/ESA in_your_country/Poland/Wspolna_wizja_i_cele_dla_przyszlosci_Europy_w_kosmosie (14.06.2017).

Wspólna wizja, wspólne działanie: silniejsza Europa. Globalna strategia na rzecz polityki zagranicznej i bezpieczeństwa Unii Europejskiej (2016), https://europa.eu/globalstrategy/sites/globalstrategy/files/eugs_pl_version.pdf (14.06.2017).

\begin{abstract}
The aim of this article is to show that the activities of the European Space Agency contribute significantly to the security of the European Union. What was required to develop space potential and to start using it for security purposes was the political and programmatic evolution of both organizations. The original objectives for which the European Space Agency was established were not related to security. Before the ESA became an organization with important implications for the security of the EU, it was an intergovernmental organization exclusively dedicated to the exploration and exploitation of space for peaceful purposes. The paper assumes that in order for this evolution to be possible, both the ESA and the EU had to find and/or develop common platforms and forms of possible cooperation. The paper identifies the most important reasons for and stages of this evolution, as expressed in program documentation. As this process is not yet complete, the remaining obstacles to the optimal use of the potential of both organizations to strengthen the security of the European Union are identified. The paper was created on the basis of the descriptive method, analysis of the content of documents and synthesis.
\end{abstract}

Keywords: European Space Agency, European Union, EU security

\title{
ZNACZENIE DZIAŁALNOŚCI EUROPEJSKIEJ AGENCJI KOSMICZNEJ DLA BEZPIECZEŃSTWA UNII EUROPEJSKIEJ
}

\section{STRESZCZENIE}

Celem artykułu jest wykazanie, że działalność Europejskiej Agencji Kosmicznej w istotny sposób przyczynia się do bezpieczeństwa Unii Europejskiej. Aby rozwinąć potencjał kosmiczny i zacząć wykorzystywać go do celów bezpieczeństwa niezbędna była ewolucja polityczna i programowa obu organizacji. Oryginalne cele, dla realizacji których powołano Europejską Agencję Kosmiczną, nie miały związku ze sprawami bezpieczeństwa. Zanim ESA stała się podmiotem mającym istotny wpływ na bezpieczeństwo Unii Europejskiej była międzynarodową organizacją międzyrządową zajmującą się wyłącznie badaniem i wykorzystaniem przestrzeni kosmicznej do celów pokojowych. W artykule przyjęto założenie, że aby ta ewolucja była możliwa, zarówno ESA, jak i UE musiały znaleźć i/lub wypracować wspólne płaszczyzny i formy możliwej współpracy. Zidentyfikowane zostaną najważniejsze przyczyny i etapy tej ewolucji znajdujące wyraz w dokumentach programowych. Proces ten nie został jeszcze zakończony, więc wskazane zostaną też istniejące nadal przeszkody utrudniające optymalne wykorzystanie potencjału obu organizacji dla wzmocnienia bezpieczeństwa Unii Europejskiej. Artykuł powstał w oparciu metodę opisową, analizę zawartości dokumentów oraz syntezę.

Słowa kluczowe: Europejska Agencja Kosmiczna, Unia Europejska, bezpieczeństwo Unii Europejskiej 